\title{
Comparison of plant nutrient contents in vermicompost from selected plant residues
}

\author{
Y. W. Yan ${ }^{1}$, A. A. Nor Azwady ${ }^{1 *}$, Z. H. Shamsuddin ${ }^{2}$, M. Muskhazli ${ }^{1}$, Suraini A. Aziz ${ }^{3}$ and \\ S. K. Teng ${ }^{1}$ \\ ${ }^{1}$ Department of Biology, Faculty of Science, Universiti Putra Malaysia, Serdang, Malaysia. \\ ${ }^{2}$ Department of Land Management, Faculty of Agriculture, Universiti Putra Malaysia, Serdang, Malaysia. \\ ${ }^{3}$ Department of Bioprocess Technology, Faculty of Biotechnology, Universiti Putra Malaysia, Serdang, Malaysia.
}

Accepted 29 August, 2012

In this experiment, earthworm, Eudrilus eugeniae was fed with different plant residues: grass clippings, sago waste and rice straw. These organic wastes were also left to decompose naturally as the control. Analysis on samples vermicompost showed that humic acid content was highest in rice straw, followed by grass clippings compared to those of sago wastes. Total phosphorus (P) was lower in vermicomposts as compared to the controls, however, highest extractable $P$ was found in rice straw vermicompost $(0.33 \pm 0.00 \mathrm{~g} / \mathrm{kg})$. Sago waste vermicompost $(22.79 \pm 0.01 \mathrm{~g} / \mathrm{kg})$ contained highest total calcuim $(\mathrm{Ca})$ compared to the grass clippings $(1.39 \pm 0.01 \mathrm{~g} / \mathrm{kg})$ and rice straw $(8.22 \pm 0.06 \mathrm{~g} / \mathrm{kg})$ vermicompost. Significant positive correlations between nutrient contents in raw plant residues and vermicompost were observed for total nitrogen $(N)(r=0.779)$, potassium $(K)(r=0.998)$ and $\mathrm{Ca}(r=$ 0.997). The study showed that nutrient in initial wastes material affects the nutrient contents of vermicompost. This research suggested that among the plant residues studied, vermicomposting of rice straw produced vermicompost with the highest plant extractable nutrient contents.

Key words: Earthworm, vermicomposting, rice straw, grass clippings, sago wastes, organic wastes, humic acids.

\section{INTRODUCTION}

Plant residues such as those originated from agricultural and municipal practices are generated in huge quantities worldwide. The annual total crop residues generated by the world population is estimated to be around 3.8 billion tonnes (Lal, 2005). These large amounts of plant residues may serve as potential sources of plant nutrients (Suthar, 2007). However, due to the lack of a cost effective and sustainable technology of waste management, disposal of organic waste unsystematically has led to pollution of the environment. Some of the major problems caused by unsustainable plant residues managements are global warming, scarcity of land and contamination of the environ-

*Corresponding author. E-mail: azwady@science.upm.edu.my.

Abbreviations: RS, Rice straw; SW, sago waste; GC, grass clippings; CD, cow dung; TN, total nitrogen. ment (Sangwan et al., 2009; Sharma et al., 2005).

Rice being the staple food source for more than $40 \%$ of the human population is a major crop grown worldwide. Globally, about 155 million hectares of land are being harvested, amounting to an annual productivity of around 800 metric tonnes of rice crop (Wati et al., 2007). Large amount of rice crop cultivations have substantially corresponded to the production of huge amount of rice straw (Pathak et al., 2006). The disposal of rice straw is a major cause of environmental concern worldwide. Generally, rice straws are chopped and openly burnt in the rice field after harvesting, thus causing air pollution to the environment.

The sago palm trunk waste produced by sago starch industries is another example of the plant residues available in large quantities but with no commercial value (Akmar and Kennedy, 2001). Both medium and large scale starch manufacturing industrial units suffer from inadequate waste treatment plant and disposal problem (Saravanane et al., 
2001). The effluent and residues resulting from sago debarking and processing are often discharged into nearby river, creating water pollution. Studies carried out have shown that these residues (commonly known as Sago hampas) are highly composed of lignin and cellulose and are therefore considered as both waste and pollutant (Vikineswary et al., 1994). Additionally, in many communities, yard trimmings are one of the major contributors to municipal wastes streams. For example, yard trimmings comprise nearly $13 \%$ of the municipal waste stream in the United States (Bary et al., 2005). The large heap of grass clippings can cause serious odour problem in composting facilities if they are not subsequently or adequately treated (Lopez et al., 2010). Application of grass clippings, especially in thick layers during household composting, will create an undisturbed and anaerobic layer where degradation is reduced, hence producing noxious odour (Michel et al., 1996). It would be interesting if these huge quantities of waste could be recycled into nutrient rich bio-fertilizer for sustainable development. Recycling of these plant residues would return a great portion of crop nutrient input during cultivation back to the soil, thus serving as an attractive waste disposal method (Suthar, 2007).

Vermicomposting offers rapid recovery of valuable resources from biodegradable wastes such as plant residues at shorter decomposition period, and faster generation of humus-like vermicompost (Pramanik et al., 2007). Addition of vermicompost is reported to have positive effects on soil chemical and physical properties (Azarmi et al., 2008). However, plant residues have different palatability, particle size, protein, crude fibre and some even contains special plant metabolites that may influence the growth and performances of earthworms as composting agent (Suthar, 2007). These factors may as well affect the quality of vermicompost produced. Application of vermicompost helps to restore nutrient loss from soil through the recycling of nutrients held in crop residues without resorting to applications of mineral fertilizers. An understanding of the differences in quality of vermicompost produced from the selected plant residues offers an insight into influence of initial materials on the nutrient status in the vermicompost produced. Therefore, the present study was conducted to evaluate the plant nutrient contents in vermicompost derived from different plant residues namely rice straw, sago waste and grass clippings.

\section{MATERIALS AND METHODS}

\section{Preparation of plant residues}

Green wastes used in this study were rice straw (RS), sago waste (SW) and grass clippings (GC). Rice straw was obtained after the paddy harvesting season from a rice field in Kedah, northern region of Peninsular Malaysia. Sago waste was obtained from a sago starch factory in Johor, Malaysia. The grass clippings used in the experiment was attained from a field in University of Putra Malaysia. Preliminary study showed that the weeds comprised of Acroceras munroanum (Balansa) Henr, Axonopus compressus (Swartz) P. Beauv and Brachiaria distachya (Linn). The plant residues were dried under sunlight, shredded and then individually mixed with cow dung (CD) in ratio of 8:2 (dry weight basis). The 8:2 ratios of plant residues and cow dung were chosen, as this is the optimal ratio for vermicompost output and maintaining earthworm's health. The cow dung was added into the plant residues to support the earthworm's growth by providing easily assimilable nutrient for the earthworm's uptake (Gajalakshmi and Abbasi, 2004).

\section{Experimental setup}

Containers $(20 \mathrm{~cm} \mathrm{D} \times 25 \mathrm{~cm} \mathrm{H})$ were filled with a total of $250 \mathrm{~g}$ of the plant residues. The experiment was conducted in a culture room (temperature: $27.0 \pm 0.5^{\circ} \mathrm{C}$ ) with 4 replicates for each treatment. Distilled water $(200 \mathrm{ml})$ was added to the plant residues to initiate decomposition process. After 2 weeks of partial decomposition period, 30 matured earthworms ( $E$. eugeniae) were introduced. Distilled water was sprinkled on the materials when necessary, to maintain moisture level of $70 \%$ (wet weight basis). The containers were covered with orchid net to reduce the loss of moisture and provide favourable condition to the earthworms. In the control, plant residues were left to undergo natural decomposition without the addition of earthworms. Samples $(10 \mathrm{~g})$ of vermicompost and control were harvested weekly, and the experiment was terminated when the C:N of approximately 20 was achieved. The $\mathrm{C}: \mathrm{N}$ ratio is considered the most reliable tool to indicate compost maturity, C:N ratio of less than 25 is considered a matured compost (Subramaniam et al., 2010). The chemical parameters of initial plant residues, control and vermicompost were analyzed.

\section{Chemicals analysis}

The $\mathrm{pH}$ was measured in a 1:10 (vermicompost : deionised water) water slurries using a digital $\mathrm{pH}$ meter (Mettler Toledo S20). Total carbon (C) was determined as organic carbon using Total Organic Carbon (TOC) analyzer. Total Kjeldahl nitrogen was analyzed using method described by Van Ranst et al. (1999). Total phosphorus (P), potassium $(\mathrm{K})$, calcuim $(\mathrm{Ca})$ and magnesium $(\mathrm{Mg})$ were measured by dry ashing (Van Ranst et al., 1999). Extractable P, K, Ca and Mg were measured using method described by Jones (2001). Humic acid content was extracted and measured by using method described by Ahmed et al. (2003).

\section{Statistical analysis}

Data were analyzed using Statistical Package for the Social Sciences (SPSS) version 16.0 and were subjected to one way ANOVA and correlation analysis. Considering the treatments as independent variables, the means were separated using Duncan test. A significance level of $p<0.05$ was considered throughout the study (Table 1).

\section{RESULTS}

The duration required for vermicomposting of SW was 4 weeks. It was recorded that $\mathrm{GC}$ and $\mathrm{RS}$ required 5 weeks to complete the vermicomposting process. The $\mathrm{pH}$ of $\mathrm{GC}$ and RS vermicompost was lower compared to SW vermicompost. $\mathrm{pH}$ changes as much as $10 \%$ were observed in vermicompost produced from initial materials with low $\mathrm{C}: \mathrm{N}$ ratio (GC and $\mathrm{SW}$ ). Besides, the produced vermicompost had significantly $(\mathrm{p}<0.05)$ lower $\mathrm{pH}$ as compared to the controls (Table 2). The $\mathrm{pH}$ range was found to be from 5.41 (GC vermicompost) to 6.32 (SW 
Table 1. Physicochemical and elemental analysis of raw materials used as initial substrates ( $\mathrm{g} / \mathrm{kg}$ ) on dry weight basis.

\begin{tabular}{lccc}
\hline Parameter & GC+CD & SW+CD & RS+CD \\
\hline $\mathrm{pH}$ & $6.06 \pm 0.06$ & $5.99 \pm 0.08$ & $6.41 \pm 0.10$ \\
Organic C & $444.33 \pm 4.01$ & $405.30 \pm 4.64$ & $385.90 \pm 12.49$ \\
Total N & $16.18 \pm 0.22$ & $14.22 \pm 0.68$ & $10.07 \pm 0.01$ \\
Total P & $2.97 \pm 0.04$ & $0.55 \pm 0.01$ & $1.25 \pm 0.10$ \\
Total K & $41.82 \pm 0.38$ & $1.06 \pm 0.04$ & $3.73 \pm 0.17$ \\
Total Ca & $13.91 \pm 0.01$ & $26.9 \pm 0.04$ & $5.54 \pm 0.18$ \\
Humic acids & $\mathrm{ND}$ & $\mathrm{ND}$ & $\mathrm{ND}$ \\
$\mathrm{C}: \mathrm{N}$ & 27.46 & 28.49 & 38.31 \\
\hline
\end{tabular}

Rice straw (RS), sago waste (SW), grass clippings (GC), cow dung (CD), not detected (ND).

Table 2. Physicochemical and elemental analysis of vermicompost and controls dry weight basis.

\begin{tabular}{lccccc}
\hline Parameter & $\mathbf{p H}$ & Total C (g/kg) & Total N (g/kg) & C:N & Humic acid (\%) \\
\hline GC vermicompost & $5.41 \pm 0.08^{\mathrm{d}}$ & $406.88 \pm 5.72^{\mathrm{a}}$ & $29.16 \pm 0.49^{\mathrm{a}}$ & 13.95 & $28.98 \pm 1.51^{\mathrm{ab}}$ \\
GC control & $6.65 \pm 0.01^{\mathrm{b}}$ & $407.15 \pm 4.94^{\mathrm{a}}$ & $27.26 \pm 0.33^{\mathrm{b}}$ & 14.93 & $32.16 \pm 5.15^{\mathrm{a}}$ \\
SW vermicompost & $6.55 \pm 0.04^{\mathrm{b}}$ & $325.63 \pm 3.72^{\mathrm{c}}$ & $15.64 \pm 0.55^{\mathrm{e}}$ & 20.81 & $22.09 \pm 2.50^{\mathrm{b}}$ \\
SW control & $6.90 \pm 0.04^{\mathrm{a}}$ & $355.23 \pm 8.86^{\mathrm{b}}$ & $17.90 \pm 0.49^{\mathrm{d}}$ & 19.85 & $27.14 \pm 3.99^{\mathrm{ab}}$ \\
RS vermicompost & $6.32 \pm 0.04^{\mathrm{c}}$ & $294.33 \pm 2.47^{\mathrm{d}}$ & $14.60 \pm 0.14^{\mathrm{e}}$ & 20.15 & $32.11 \pm 2.26^{\mathrm{a}}$ \\
RS control & $6.94 \pm 0.07^{\mathrm{a}}$ & $354.15 \pm 1.57^{\mathrm{b}}$ & $20.23 \pm 0.15^{\mathrm{c}}$ & 17.50 & $24.00 \pm 3.67^{\mathrm{ab}}$ \\
\hline
\end{tabular}

Mean values followed by different letters in same column are significantly different (ANOVA; Duncan's test, $p<0.05$ ).

vermicompost). After undergoing vermicomposting by passing through the gut of earthworms, organic carbon reduction of 8 to $24 \%$ was observed in the vermicompost formed. Largest reduction $(92 \mathrm{~g} / \mathrm{kg})$ in organic carbon was obtained in RS vermicompost, whereas the initial C:N was the highest (38), indicating that the large amount of $C$ present in raw material RS can be assimilated by the earthworms. Reduction of carbon amounting to $80 \mathrm{~g} / \mathrm{kg}$ was found in SW vermicompost from its initial material. However, the lowest reduction of organic $C$ was found in $\mathrm{GC}$ vermicompost, amounting to only $37 \mathrm{~g} / \mathrm{kg}$ reduction of $\mathrm{C}$ after vermicomposting (Table 2).

Analysis of vermicompost showed that total $\mathrm{N}$ was the highest in GC, twice the amount of $\mathrm{N}$ found in SW and RS vermicompost (Table 2). SW and RS vermicompost containing low total $\mathrm{N}$ were produced, as the initial plant residues (SW, $14.22 \mathrm{~g} / \mathrm{kg}$; RS, $10.07 \mathrm{~g} / \mathrm{kg}$ ) used for vermicomposting contained low $\mathrm{N}$ content. GS, SW and $R S$ vermicompost yielded significantly lower total $P$ compared to the controls (Figure 1a). However, extractable $P$ was found to be significantly higher in all vermicompost compared to controls. In fact, RS vermicompost contained twice the amount of extractable $P$ to those of RS controls. Similar trend was observed for K (Figure 1b); higher amount of total $\mathrm{K}$ was observed in control compared to vermicompost. Extractable $\mathrm{K}$ in RS vermicompost was 4 times higher than RS control, 5 times higher than SW vermicompost and SW control. Significant differences in extractable $\mathrm{K}$ content were found for all vermicompost and naturally decomposed materials, except for vermicompost and control of SW.

Highest amount of total Ca was found in SW vermicompost while RS vermicompost contained the lowest total $\mathrm{Ca}$. However, it was found that RS vermicompost contained the highest amount of extractable $\mathrm{Ca}$ (Figure 1c). SW and RS vermicompost showed significantly higher total calcium content compared to SW and RS control. Total $\mathrm{Ca}$ content was significantly lower in GC vermicompost compared to its GC control. Extractable $\mathrm{Ca}$ also showed no significant difference between vermicompost and control, except for RS vermicompost and control. Highest amount of extractable $\mathrm{Ca}$ was found in RS vermicompost when compared to all other treatments. Humic acids content was recorded to be the highest in RS vermicompost compared to GC and SW vermicompost (Table 2). Significant difference in humic acid content was only recorded between RS and SW vermicompost. No significant difference was found in humic acid content between vermincompost and controls.

Significant positive correlation was observed for total N between the initial materials and vermicompost $(r=0.77)$. Besides, positive correlations were obtained between the total macronutrients ( $\mathrm{K}$ and $\mathrm{Ca}$ ) in both vermicompost and control and the type of raw materials. Strong positive correlations were observed for total $\mathrm{K}$ in vermicompost $(r=0.99)$ and control $(r=0.98)$. Nevertheless, total $\mathrm{Ca}$ 

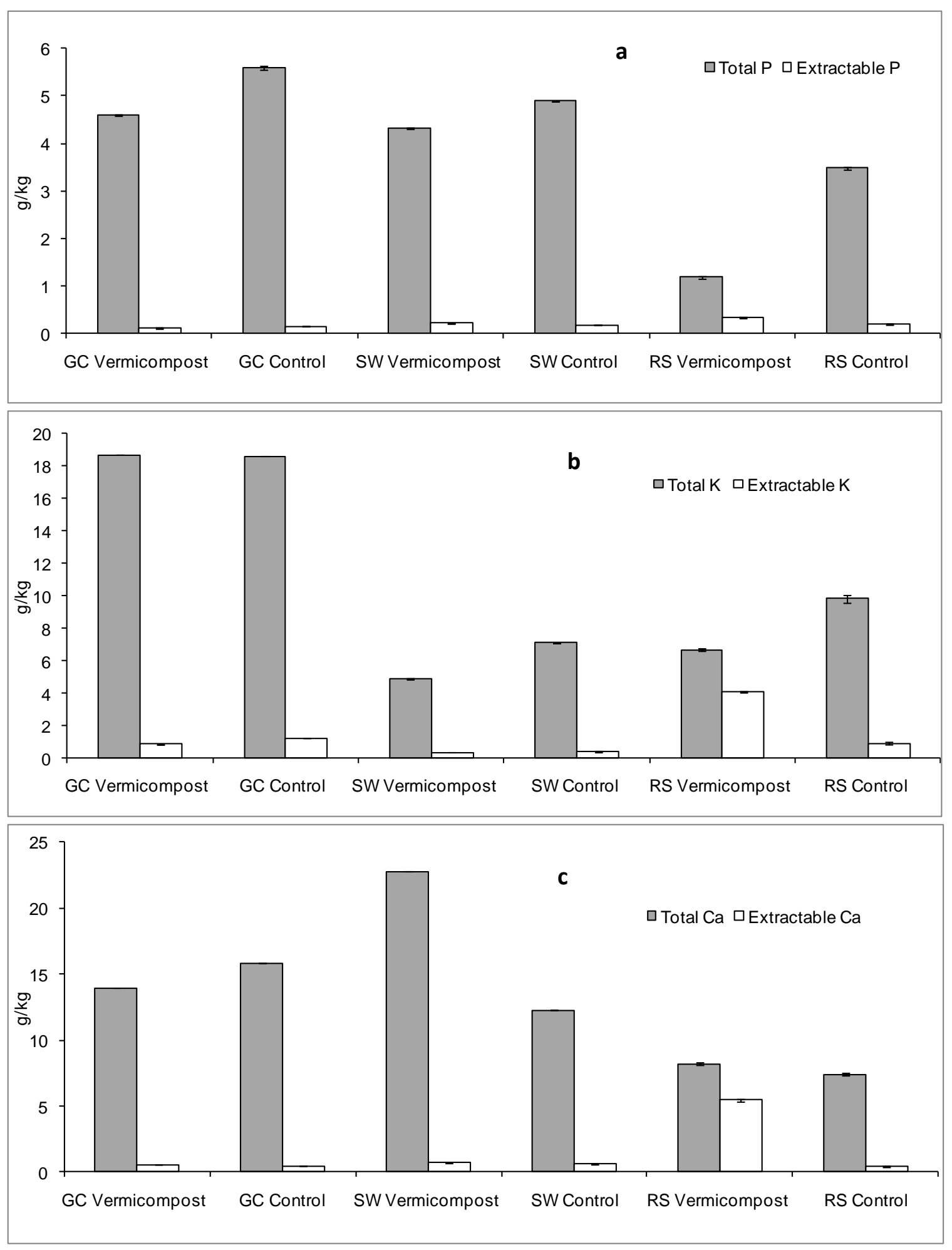

Figure 1. Average (mean \pm standard error) of plant nutrient contents in vermicompost and control (a) total and extractable phosphorus, (b) total and extractable potassium, (c) total and extractable calcium.

only showed significant positive relationship between raw materials and vermicompost $(r=0.99)$. Significant negative correlations were found between raw materials and extractable $P$ in vermicompost $(r=-0.62)$ and control $(r=$ -0.69). Extractable calcium showed negative correlation between raw materials and vermicompost $(r=-0.78)$. 


\section{DISCUSSION}

Our study showed that the $\mathrm{pH}$ of SW vermicompost was near neutral. Nevertheless, in RS and GC vermicompost, lower $\mathrm{pH}$ was observed. A vermicompost derived from sheep manure has a pH of 8.6 (Gutierrez-Miceli et al., 2007) while $\mathrm{pH}$ of vermicompost derived from cattle manure was 7.73 (Lazcano et al., 2008). The pH of vermincompost derived from pig manure was even found to have $\mathrm{pH} 5.3$ (Atiyeh et al., 2002). The pH shift during vermicomposting is not only dynamic but is substrate dependent. A different substrate would result in the formation of a different intermediate, hence portray a difference in $\mathrm{pH}$ of the vermicompost formed (Ndegwa et al., 2000).

During the degradation of organic materials, ingestion of organic materials by the earthworm would partially be degraded by mechanical effort, enzymatic activity and microorganism from the earthworm gut (Svensson and Friberg, 2007). Sago wastes contain more easily assimilable labile organic materials which may lead to less secretion of organic acids by microbes during vermicomposting. The organic acids secreted by the microbes during vermicomposting are known to be subsequently utilized (Jadia and Fulekar, 2008). However, organic wastes that contained more lignocellulosic materials (RS and GC) may require more action from earthworms in fragmenting and stimulating growth of microbes thus, larger amount of organic acids were secreted during vermicomposting, resulting in formation of vermicompost with lower $\mathrm{pH}$. Reduction in organic carbon content was found in all the vermicompost. This might be due to its loss as $\mathrm{CO}_{2}$ during respiration and metabolism of earthworms and microbes (Garg et al., 2006a, b; Sudha and Kapoor, 2000). Labile carbon in the feed substrate is also assimilated into building body biomass of earthworms. Our study showed that highest reduction in organic carbon was observed in RS vermicompost. This might be due to the highest $\mathrm{C}: \mathrm{N}$ of initial material rice straw, as more organic carbon was available for utilization of earthworms. Although the $\mathrm{C}: \mathrm{N}$ ratio of grass clippings was higher compared to sago waste, the reduction of organic carbon was found to be less in GC vermicompost compared to that of SW vermicompost. This indicates that the grass clippings were less consumed by the earthworms. Previous study has shown that lactic acids and acetic acids intermediates that are quickly released from lawn clippings under oxygen lacking conditions were the most important factor preventing earthworms Eisenia fetida from tolerating high concentrations of grass clippings (IIImer and Liebensteiner, 2011). This might explain why GC vermicompost in the present study contained the highest organic carbon as compared to other vermicompost.

Concentration of total plant macronutrients ( $\mathrm{N}$ and $\mathrm{P})$ in GC, SW and RS vermicompost were found to increase compared to the concentration of nutrients held in initial plant residues. The loss of dry matter during vermicompos- ting may result in the accumulation of higher concentration of inorganic nutrients in the vermicompost. Study by Sommer (2000) has shown that the concentration of $P$ had increased as a consequence of the reduction in amount of litter. This increased concentration of inorganic nutrient in vermicompost, in combination with reduction of the volume and weight of the initial raw organic wastes, pose great advantages. Through this, vermicomposting reduces the cost of handling and transportation of large volume of organic waste. Similarly, increased of total N and $P$ was found in the controls of GC, SW and RS. This observation could also be due to the accumulation of inorganic nutrients when the plant residues were left to undergo natural decomposition. However, it was found that the total nutrient $\mathrm{P}$ and $\mathrm{K}$ was higher in control. The results suggest that some portion of nutrient in the plant residues was taken up by the earthworms during vermincomposting. Hence, lower total $\mathrm{P}$ and $\mathrm{K}$ nutrient was found in vermicompost.

GC vermicompost has highest total nitrogen (TN) compared to SW and RS vermicomposts. The lowest reduction of total carbon in GC vermicompost suggests that microbes in SW and RS vermicompost might have required large amount of nitrogen during the reduction of carbon in vermicomposting. Previous work has suggested that the microbes require 1 part of nitrogen to decompose 30 part of carbon (Yadav et al., 2010). The low reduction of organic carbon content during vermicomposting of grass clipping may help retain higher total nitrogen in the vermincompost. In addition, our study has shown significant positive correlation of total nitrogen between raw material and vermicompost. This suggests that using materials which contain high total $\mathrm{N}$ as the feed substrate might promote the production of vermicompost containing higher $\mathrm{N}$.

Total $P$ (TP) in vermicompost and control materials were higher compared to the initial raw materials as reported by many authors Garg et al. (2006b), Kaushik and Garg (2004) and Tripathi and Bhardwaj (2004). However, certain portion of TP in organic wastes has been taken up by earthworms, resulting in lesser TP in the vermicompost (Ndegwa et al., 2000). On the other hand, earthworms have increased extractable $P$ in vermicompost. Some authors attributed this increment to direct action of earthworm gut enzymes and indirectly by stimulation of the microflora in earthworm's cast (Kaushik and Garg, 2004; Suthar, 2007). According to Suthar (2008), the partial release of phosphorus in a more available form was performed by the earthworm gut phosphatises, and further release of $P$ might be attributed to microorganism in the earthworm's cast. With the gizzards, the earthworms are able to grind on the organic waste consumed, thus increasing surface area for microbial activity. Study by Mansell et al. (1981) showed that plant litter contained more available $P$ after ingestion by earthworms; this could be attributed to the increase of physical breakdown of the plant material.

RS vermicompost contained the highest concentration 
of extractable P. Furthermore, our results have shown negative correlation for extractable $P$ between the nutriaent contents of raw material and vermicompost. Interestingly, this finding indicates the potential of earthworms in solubilizing raw waste materials that contain low amount of total $P$. It has been reported that the release or mobilezation of $P$ is strongly mediated by a negative feedback mechanisms, which is through the inhibition of P-solubilizing enzymes production (Elfstrand et al., 2007). In other words, keeping the $\mathrm{P}$ level supply at low levels that do not exceed the demand of biota will stimulate production of enzymes, hence stimulating the $P$ solubilization. The negative correlation between enzyme activity and nutrient availability are consistent with a negative feedback mechanism whereby the production or activity of enzyme is regulated by a supply of nutrient that the enzyme mineralizes (Sinsabaugh, 1994). The negative feedback mechanisms could be the primary way microbes regulate mineralization of nutrient in response to the nutrient supply (Olander and Vitousek, 2000). This negative relationship between nutrient supply and enzyme activity in vermicomposting has not been previously reported.

High positive correlation was found for the amount of $\mathrm{K}$ between raw materials and vermicompost. Different findings were obtained in terms of changes in total potassium (TK) after vermicomposting. TK was found to increase in the SW and RS vermicompost. However, plant residue GC was found to contain higher TK compared to both vermicompost and control. Study by Vig et al. (2011) showed that TK decreased significantly from the initial feed material by the end of vermicomposting period. Other studies conducted by Kaur et al. (2010), Garg et al. (2006b) and Orozco et al. (1996) recorded similar trend. However, increase of TK was reported by Swati and Reddy (2010) during vermicomposting of urban green wastes. This suggests that the different changes in total $\mathrm{K}$ may be attributed to the type of green wastes used as vermibed. Further research should be done to investigate the factors that contribute to different potassium in vermicompost, as TK plays possible roles in plant growth promotion.

Extractable $\mathrm{K}$ was found highest in $\mathrm{RS}$ vermicompost. The increase of the extractable $\mathrm{K}$ may be attributed to both the actions of earthworms and microbes activities during vermicomposting. Similar result was obtained by Suthar and Singh (2008) who reported that extractable K increased during the vermicomposting of vegetable wastes. The interaction between earthworms and microorganisms is of major importance in degradation of organic matter and release of microbial nutrients (Lee, 1985; Aira et al., 2002), as earthworm primes its symbiotic gut microflora with secreted mucus and water to increase their degradation of ingested organic matter and the release of available metabolites. Acid production by microorganisms is accounted for in the prime mechanisms for solubilising the insoluble K (Gupta et al., 2006). The low amount of TK in the initial material RS could promote higher amount of microbial acid secretion. This might attribute to the higher amount of extractable $\mathrm{K}$ found in RS vermicompost.

Analysis of nutrient contents in the plant residues and nutrient contents in vermicompost generated showed strong positive correlation in total calcium (TCa). Higher amount of calcium in vermibed materials would promote more calcium in earthworm's casts. As shown in SW vermincompost, initial material sago wastes which contains high amount of calcium has stimulated the earthworm to produce vermicompost with the highest TCa. The presence of calciferous gland in most of the epigeic earthworms might explain the increase of $\mathrm{TCa}$ in the vermincompost produced. A common feature of this structure is the release of calcareous secretion which would be deposited as calcite in the esophageal pouches (Briones et al., 2008). The calcite would then be released into the gut of the earthworms. Through the secretion of calcium carbonates, the earthworms control their dietary intake of calcium, allowing them to survive in various environments. Edwards and Bohlen (1996) has considered the calciferous gland as an excretory organ to eliminate excess dietary calcium in form of calcium carbonate from the earthworm's diet. This mechanism aids in excreting excessive amount of calcium from the body of earthworms.

During vermicomposting, the microbes in the gut might produce organic acids to hydrolyze the organic materials available. The calciferous glands are also claimed to be important in regulating the $\mathrm{pH}$ in the ingested food and environment of the earthworm by regulating the amount of calcium carbonate released to neutralize acidic environment surrounding the earthworms. This excretion plays particularly important role in neutralizing humic acids of the ingested feed litter in the gut of earthworms (Piearce, 1972). Therefore, the high percentage of humic acids in rice straw might contribute to the high extractable $\mathrm{Ca}$ in RS vermicompost. Increase of humic acid in the vermincompost as compared to the initial material was observed. It has been reported that while a large part of organic matter is mineralized into carbon dioxide, ammonia and water during vermicomposting, the residual portion is transformed into stabilized and refractory organic matter that resembles native soil humus material (Benitez et al., 1999). Our results showed that rice straw vermicompost contained the highest amount of humic acids. The rice straw might contain high lignin content, leading to the formation of high amount of humic materials in RS vermicompost. Modern analytical technique has suggested that the oxidation of the side chain of lignin is the main process occurring during the transformation of lignin to the humic structure (Xiong et al., 2010). The final products of lignin decomposition through microorganisms are humic material (Pramanik et al., 2009).

To date, little study has been done on the humic acids content in vermicompost generated (Arancon et al., 2006; Atiyeh et al., 2002). The present study showed that 22 to $32 \%$ of humic acid was present in the vermicompost. This demonstrates the ability of vermicomposting to produce 
high quality humified product that contains aesthetic value to be used as soil conditioner. Humic acids are believed to enhance nutrient uptake by plants, by increasing the permeability of root cell membrane (Atiyeh et al., 2002; Valdrighi et al., 1996). Besides that, plant nutrients are carried on the cation and chelating sites of the humic acid. These large chelating sites serve as storage for large quantity of nutrients for the growth of both plants and microbial growth (Tan, 2003). Hence, the synergetic relationship between earthworms and microorganisms in the decomposition of organic wastes has yielded a fertilizer with high nutrient availability. Besides the recovery of energy rich resources, vermicomposting aids in safely disposing of organic wastes.

\section{Conclusion}

The current generation of surplus quantities of biodegradable organic substrates such as agricultural residues, food processing wastes, and cellulose based wastes have made vermicomposting a viable low input and cost effective technology in managing organic wastes; though the total plant macronutrients generated in vermicompost were lower compared to control, as some of the nutrients were assimilated by the earthworms. Due to the ability of earthworm to decompose organic material into the more available form for plant uptake, higher plant extractable nutrients which are more meaningful and beneficial to the agro ecosystems perspective were observed in vermicompost. The study also suggests that the nutrient contents in initial plant residues will influence the quality of vermicompost produced. An estimation of the quality of vermicompost produced from plant residues of similar characteristic can be drawn. This research has proved that among the plant residues tested, vermicomposting of rice straw produced vermicompost with the highest plant extractable nutrient contents.

\section{ACKNOWLEDGEMENT}

We would like to thank the Ministry of Science, Technology and Innovation (MOSTI) for providing the funds for this research through Science Fund grant 05-01-04SF0641.

\section{REFERENCES}

Ahmed OH, Husni MHA, Anuar AR, Hanafi MM (2005). Effects of extraction and fractionation time on yield of compost humic acids. $\mathrm{N}$. Z. Crop Hort. Sci. 33(2):107-110.

Aira M, Monroy F, Dominguez J, Mato S (2002). How earthworm density affects microbial biomass and activity in pig manure. Eur. J. Soil Biol. 38:7-10.

Arancon NQ, Edwards CA, Lee S, Bryne R (2006). Effects of humic acids from vermicomposts on plant growth. Eur. J. Soil Biol. 42(1)65-69.

Akmar PF, Kennedy JF (2001). The potential of oil and sago palm trunk wastes as carbohydrate resources. Wood Sci. Technol. 35(5):467-473.
Atiyeh RM, Lee S, Edwards CA, Aracon NQ, Metzger JD (2002). The influence of humic acids derived from earthworm-processed organic wastes on plant growth. Biores. Technol. 84:7-14.

Azarmi R, Giglou MT, Taleshmikail RD (2008). Influence of vermicompost on soil chemical and physical properties in tomato (Lycopersicum esculentum) field. Afr. J. Biotechnol. 7(14):2397-2401.

Bary Al, Cogger CG, Sullivan DM, Myhre EA (2005). Characterization of fresh yard trimmings for agricultural used. Biores. Technol. 96:14991504.

Benitez E, Nogales R, Elvira C, Masciandaro G, Ceccanti B (1999). Enzyme and earthworm activities during vermicomposting of carbaryl-treated sewage sludge. J. Environ. Qual. 28:1099-1104.

Briones MJI, Ostle NJ and Piearce TG (2008). Stable isotopes reveal that the calciferous gland of earthworms is a $\mathrm{CO}_{2}$ fixing organ. Soil Biol. Biochem. 40: 554-557.

Edwards CA, Bohlen PJ (1996). Earthworm morphology. In: Biology and ecology of earthworms, $3^{\text {rd }} \mathrm{Ed}$, Chapman and Hall, London, United Kingdom, p. 13.

Elfstrand S, Bath B, Martensson A (2007). Influence of various forms of green manure amendment on soil microbial community composition, enzyme activity and nutrient levels in leek. Appl. Soil Ecol. 36:70-82.

Garg VK, Yadav YK, Sheoran A, Chand S, Kaushik P (2006a). Livestock excreta management through vermicomposting using an epigeic earthworm Eisenia foetida. Environment 26:269-276.

Garg P, Gupta A, Satya S (2006b). Vermicomposting of different types of waste using Eisenia fetida: A comparative study. Biores. Technol. 97(3):391-395.

Gutierrez-Miceli FA, Santiago-Borraz J, Molina JAM, Nafate CC, AbudArchila M, Llaven MAO, Rincon-Rosales R, Dendooven L (2007). Vermicompost as a soil supplement to improve growth, yield and fruit quality of tomato (Lycopersicum esculentum). Biores. Technol. 98(15):2781-2785.

Illmer P, Liebensteiner M (2011). Use of avoidance test for investigating potential of the earthworm Eisenia fetida to improve composting of grass clippings. Compost Sci. Util. 19(2):123-128.

Jones JB (2001). Laboratory guide for conducting soil tests and plant analysis. CRC Press, Florida, United States of America.

Jadia CD, Fulekar MH (2008). Vermicomposting of vegetables wastes: Bio-physicochemical process based on hydro-operating bioreactor. Afr. J. Biotechnol. 7(20):3723-3730.

Kaur A, Singh J, Vig AP, Dhaliwal SS, Rup PJ (2010). Cocomposting with and without Eisenia fetida for conversion of toxic paper mill sludge to a soil conditioner. Biores. Technol. 101:21 8192-8198.

Kaushik P, Garg VK (2004). Dynamics of biological and chemical parameters during vermicomposting of solid textile mill sludge mixed with cow dung and agricultural residues. Biores. Technol. 94:203-209.

Lal R (2005). World crop residual production and implications of its use as biofuel. Environ. Int. 31:575-584.

Lazcano C, Gomez-Brandon M, Dominguez J (2008). Comparison on effectiveness of composting and vermicomposting for the biological stabilization of cattle manure, Chemosphere 72(7):1013-1019.

Lee KE (1985). Earthworms: Their ecology and relationship with soil and land use, Academic Press, Sdyney, Australia, p. 411.

Lopez M, Soliva M, Farre FXM, Bonmati A, Pujol OH (2010). An assessment of the characteristics of yard trimmings and recirculated yard trimmings used in biowaste composting. Biores. Technol. 101(4):1399-1405.

Mansell GP, Syers JK, Gregg PEH (1981). Plant availability of phosphorus in dead herbage ingested by surface-casting earthworms. Soil Biol. Biochem. 13(2):163-167.

Michel FC, Huang JF, Forney LJ, Reddy A (1996). Field scale study of the effect of pile size, turning regime and leaf to grass mix ratio on the composting of yard trimmings. In: Bertoldi MD, Sequi $P$, Lemmes B, Papi T. The Science of Composting, Blackie Academic and Professional, London.

Ndegwa PM, Thompson SA, Das KC (2000). Effects of stocking density and feeding rate on vermicomposting of biosolids. Biores. Technol. 71:5-12.

Olander LP, Vitousek PM (2000). Regulation of soil phosphatase and chitinase activity by $\mathrm{N}$ and $\mathrm{P}$ availability. Biogeochemistry 49:175-190.

Orozco FH, Cegarra J, Trujillo LM, Roig A (1996). Vermicomposting of coffee pulp using the earthworm Eisenia fetida: Effects on $\mathrm{C}$ and $\mathrm{N}$ 
contents and the availability of nutrients. Biol. Fert. Soils 22:1(2) 162166.

Pathak H, Singh R, Bhatia A, Jain N (2006). Recycling of rice straw to improve wheat yield and soil fertility and reduce atmospheric pollution. Paddy Water Environ. 4:111-117.

Piearce TG (1972). The calcium relations of selected Lumbricidae. J. Anim. Ecol. 41(1): 167-188.

Pramanik P, Ghosh GK, Chosal PK, Banik P (2007). Changes in organic - C, N, P and $\mathrm{K}$ and enzyme activities in vermicompost of biodegradable organic wastes under liming and microbial inoculants. Biores. Technol. 98:2485-2494.

Pramanik P, Ghosh GK, Banik P (2009). Effect of microbial inoculation during vermicomposting of different organic substrates on microbial status and quantification and documentation of acid phosphatase. Waste Manage. 29(2):574-578.

Sangwan P, Kaushik CP, Garg VK (2009). Vermicomposting of sugar industry waste (press mud) mixed with cow duing employing an epigeic earthworm Eisenia fetida, Waste Manage. Res. 28: 71-75.

Saravanane R, Murthy DVS, Krishnaiah K (2001). Anaerobic fluidized bed degradation and the development of a kinetic model for a particulate organic matter enriched wastewater sludge. Water, Air Pollut. 127:15-30.

Sinsabaugh RL (1994). Enzyme analysis of microbial pattern and process. Biol. Fertil. Soils 17:69-74.

Sommer SG (2000). Effect of composting on nutrient loss and nitrogen availability in cattle deep litter. Eur. J. Agro. 14(2):123-133.

Sharma S, Pradhan K, Satya S, Vasudevan P (2005). Potentiality of earthworms for waste management and other uses - a review. J. Am. Sci. 1(1):4-16.

Subramanian S, Sivarajan M, Saravanapriya S (2010). Chemical changes during vermicomposting of sago industry solid wastes. J. Hazard. Mat. 179:1-3

Sudha B, Kapoor KK (2000). Vermicomposting of crop residues and cattle dung with Eisenia fetida. Biores. Technol. 73(2):95-98.

Suthar S (2007). Nutrient changes and biodynamicfs of epigeic earthworm Perionyx excavatus (Perrier) during recycling of some agricultural waste. Bioresour. Technol. 98:1608-1614.

Suthar S (2008). Bioconversion of post harvest crop residues and cattle shed manure into value added products using earthworm Eudrilus eugeniae. Ecol. Eng. 32:206-214.

Suthar S, Singh S (2008). Vermicomposting of domestic waste by using two epigeic earthworms (Perionyx excavatus and Perionyx sansibaricus). Int. J. Environ. Sci. Technol. 5(1):99-106.

Svensson K, Friberg H (2007). Changes in active microbial biomass by earthworms and grass amendments in agricultural soil. Biol. Fertil. Soils. 44(1):223-228.

Swati P, Reddy MV (2010). Nutrient status of vermicompost of urban green waste processed by three different earthworm species- Eisenia fetida, Eudrilus eugeniae and Perionyx excavatus. Appl. Environ. Soil Sci. pp. 1-13.
Tan KH (2003). Humic matter in soil and environment principles and controversies, Marcel Dekker, Inc, New York, United States of America, pp. 178-205.

Tripathi G, Bhardwaj P (2004). Decomposition of kitchen waste amended with cow manure using an epigeic species (Eisenia fetida) and anecic species (Lampito mauriti). Biores. Technol. 92(2):215-218.

Valdrighi MM, Pera A, Agnolucci M, Frassinetti S, Lunardi D, Vallini G (1996). Effects of compost-derived humics acids on vegetable biomass production and microbial growth within a plant (Cichorium intybus)-soil system: A comparative study. Agric. Ecosyst. Environ. 58:2(3):133-144.

Van Ranst E, Verloo M, Demeyer A, Pauwels JM (1999). Manual for the soil chemistry and fertility laboratory analytical methods for soils and plants equipment and management of consumables, University of Ghent, Belgium, pp. 166.

Vig AP, Singh S, Wani SH, Dhaliwal SS (2011). Vermicomposting of tannery sludge mixed with cattle dung into valuable manure using earthworm Eisenia fetida (Savigny). Biores. Technol. 102(17):79417945.

Vikineswary S, Shim YL, Thambirajah JJ, Blakebrough N (1994). Possible microbial utilisation of sago processing wastes. Resour. Conserv. Recyc. 11:289-296.

Wati L, Kumari S, Kundu BS (2007). Paddy straw as substrate for ethanol production. Indian J. Microbiol. 47:26-29.

Xiong X, Li Y, Yang M, Zhang FS, Li W (2010). Increase in complexation ability of humic acids with the addition of ligneous bulking agents during sewage sludge composting. Biores. Technol. 101: 9650-9653.

Yadav KD, Tare V, Ahammed MM (2010). Vermicomposting of source separated human faeces for nutrient recycling. Waste Manage. 30(1):50-56. 